\title{
Sindh Education Sector Plans' Conundrums toward Enhancing Equity Access to Education for All in the Region
}

\author{
Mr. Muhammed Nawaz Sohoo \\ Director of General Mining and Minerals Development Department, \\ Government of Sindh Karachi Pakistan. \\ Dr. Hamzo Khan Tagar \\ Director Public Private Partnership Node, \\ School Education \& Literacy Department, \\ Government of Sindh, Karachi Pakistan. \\ Mr. Sheraz Ali \\ Senior Manager, Sindh Education-MIS, \\ Reform Support Unit, School Education and Literacy Department, \\ Government of Sindh, Pakistan. \\ Mr. Abdul Karim Tagar \\ Research Associate (MS Fellow), \\ University of Sindh Jamshoro, Sindh. \\ Mr. Ghulam Ali Bijarni \\ District Head Local Support Unit, \\ School Education \& Literacy Department, \\ Government of Sindh, Karachi Pakistan.
}

\begin{abstract}
The basic aim of the paper is to critically evaluate the Sindh school education sector plans (i.e. First plan 2014-18, and second sector plan, 2019-24) as a case study. It also attempts to find missing links of enhancing education access to girls as a policy tool in greater human interest. Paper also provides recommendations for improvement in the proposed plan in public interest. The Study concludes that investment in the education of girls may well be the highest-return investment available in the developing world so plans, policies, and programs must be focused on access educational incentives to girls for sustainable economic growth and development.
\end{abstract}

Keywords: Sindh Education Sector Plan (SESP), School Education System, Literacy, Challenges, Opportunities, Gender Progress, Quality Education, Missing Links, Sustainable Development Goals (SDGs)

\section{INTRODUCTION}

Globally 7.7 billions of inhabitants estimated in the 235 countries of the world, therein Pakistan ranked $5^{\text {th }}$ most populous country on the planet, having 216.57 million residents, which is a $2.8 \%$ share of the world population [1]. Sindh is Pakistan's second-most populated province, having more than 50 million people, majority of folks are very young at least $60 \%$ are estimated to be under the age of 15 and $50 \%$ are under 24 years. Though Sindh province is the most urbanized province in the country, wherein about half of the total inhabitants living in the urban areas, however, above $40 \%$ illiterate in the province and the ratio of illiterate girls is 
comparatively more than boys [2]. The United Nations Deployment Program concludes that the residents of Sindh, particularly in rural areas are affected by illiteracy multiple forms of poverty and considerable disparities exist between districts of the province. It is estimated that $43 \%$ of Sindh's population suffers from multiple forms of poverty, which would add up to 21 million people reflected in the latest census of 2017. "Differences between urban and rural areas in Sindh are substantial. Multidimensional poverty affects three in four people living in rural areas of Sindh, compared to one in ten of those who live in urban areas". [3]

In terms of literacy, Sindh rates are comparatively low then national averages, (55\% in Sindh, $58 \%$ in Pakistan). Child health is also an issue: infant and maternal mortality rates are above the country averages and many children are underweight, stunted, or wasted.' Sindh accounts for approximately $27.5 \%$ of the national GDP. "The provincial government's budget for education grew from $13.4 \%$ of the total allocation in 2011, to $18.5 \%$ in 2017".[4]The Sindh Right of Children to Free and Compulsory Education Act 2013/Rules 2017 was developed to implement Article 25A of the constitutions of Pakistan. "The act defines free education to include not only free of charges in public schools, but also to include textbooks, stationery, schoolbags, and uniforms. This is a mandatory requirement for private schools to deliver education to $10 \%$ of their intake without charges for 05 to 16 years peoples". [5]

The education services' delivery in Sindh schools is the main responsibility of the School Education \& Literacy Department. The Special Education Department, the College Education Department and the Higher Education Department are also functional in the province but not the part of the plan. The plans' are an emphasis on School Education \& Literacy Department only. However, an important step toward free and quality pre-school services in the province was the development of the Early Childhood Care and Education (ECCE) Policy Sindh 2015, and the development of the ECCE curriculum (2017).

The Sindh Non-Formal Education (NFE) Policy 2017 are also part of the revised plan 2019-24, to ensure that no child is out of school, by providing opportunities to complete primary and post-primary education through non-formal education and regular program of schoolings. The technical and vocational skills program of improvement is also included for employable opportunities for students at large. The Sindh Curriculum and Standards Act 2014 and the number of other laws address the provision of education services in Sindh are also included in the second plan but the question of implementations' gap and slow pace of progress is major obstacles to the plan which needs to address in strategic planning. The Public-Private Partnership Act 2010, and its amendment in 2014/15, provides a framework for Public-Private Partnerships (PPP) in all sectors, including schools education and literacy department are also significant milestones in the sector planning within the next 05 years. These education policies or institutional frameworks planned and developed in the period (2014-2018) and which also guide the strategies of the sector plan relate to: Management Cadre, Gender Unit, Teacher Recruitment, Disaster Risk Reduction, Monitoring \& Evaluation, and School Consolidation. "The above referred initiatives are in relevance at the international level because of Sindh-Pakistan has committed to pursuing the Sustainable Development Goals (SDGs) 2030, and in particular goal 04 , which aims to ensure inclusive and equitable quality education and promote lifelong learning opportunities for all in the region." [6]

Caroline Pearce and Kjersti J. Mowé,(2014) emphasis on Evaluation and research of the plan and explained in details that 'Evaluation is usually carried out at the midterm and at the end of the Education. Sector Plan period. Often, it is a process led by independent personnel in order to guarantee objectivity. An evaluation tests the premises upon which the education sector plan is built and provides guidance for future plan development. It may lead to rethinking the 
Plan's priorities and targets fully. "The intent of the final review is not only to evaluate impacts and outcomes, relevance, cost-effectiveness, and sustainability, but also to analyses the reasons certain results have or have not been achieved, and to derive lessons for policy revision and for preparing the next medium-term plan. Civil society, as a member of the Local Education Group (LEG), should use evidence-based research and expertise to be involved in this activity". [7]

Lawrence Summers, a renowned economist concludes "investment in the education of girls may well be the highest-return investment available in the developing world so plan, policy and the program must be focused on access to educational incentives on girls".[8]

Klasen, Stephan (2002), emphasis the educational enhancements to girls and said that "Women's education is one of the major explanatory variables behind the rates of social and economic development". [9]

(Husain et al, 2003), concludes that "Human capital is one of the essential factors for economic growth. Women, as half of the populations have a great impact on the development of the community and their participation in the social field is essential for Scio economic development" [10].

(Praveen, 2008), concludes that the Women literacy rate plays a vital role to enhance the economic development of nationwide. The advancement of society relies on the efficiency of its educational systems that provides the same prospects of getting an education to everyone. She emphasized the impact of female literacy on the development of the economy is essential for the rapid progress of society. [11]

(Dauda, 2012), concludes in the case of Nigeria that "Female education plays a vital role in the reduction of poverty and contributes to sustainable growth in developing nations. So, the attention must be paid to the promotion of female education for structural transformation and economic growth". [12]

Syeda Anam Hassan \& Nazish Rafaz (2016), concludes that only Female education will reduce the level of fertility rate which will be helpful for growth and development in long term planning and prosperity of the nations it further suggest more investment and policy access towards girls' education. [13]

Tagar Hamzo Khan (2019) concludes and suggest in his study on female literacy trends in Pakistan that "There should be separate coherent planning and educational development strategy for reaching to the out-reach girls and disadvantage female groups to enhance their capacity and capabilities with more focus on survival rates of already enrolled females in the schools and to minimizing the dropout from female schools due to the above discussed major obstacles prevail in Pakistani society".[14]

Chang, G.C.; Radi, M.( 2001) concludes that "a simulation model for sector planning can be used for result based planning in the education sector and it requires the collection of the most relevant and reliable data and the quantifying of policy decisions and pedagogical choices, and it also makes it possible for the system's dynamic evolution to be represented in human, technical, physical, and budgetary terms, and evaluate the effects of the different decisions of the education policy. It provides objective information to facilitate the dialogue on the quantitative, qualitative, and financial consequences of policy decisions; if regularly updated, it makes it possible to avoid the dysfunctions and the deviations in the management of the education system's development".[15] 
UNESCO (2010a) elaborates on the major differences between the traditional planning approach, which was commonly practiced in the education sector until the late 1990s, and the more recent strategic planning approach adopted in an increasing number of countries. The strategic planning approach implies a more fundamental challenge of building up a new management culture based on the values of participatory decision-making, accountability, and openness for change. This is a process that needs time to produce results, particularly in countries in which some of the most basic conditions for an efficient public the service system are simply not fulfilled.

Table-01

\begin{tabular}{|l|l|}
\hline Traditional Planning & Strategic Planning \\
\hline Input-oriented & Result-oriented \\
\hline Technocratic & Participatory \\
\hline Neutral & Mobilization instrument \\
\hline Linear planning & Iterative planning \\
\hline Rigid implementation & Flexible implementation \\
\hline Routine-based & Change-oriented \\
\hline Compliance monitoring & Performance monitoring \\
\hline Emphasis on the plan document & Emphasis on plan implementation \\
\hline
\end{tabular}

[16]

Global Gender Report (2020) of the World Economic Forum declared Pakistan as the lowest performer in the gender gap and keeps it at $3^{\text {rd }}$ to last among 153 countries in the education sector, Pakistan is still failed to fill the gender gap in the education sector. "Less than half of the women are illiterate compared with $71 \%$ of men, while a share of women enrolled is systemically lower than the share of men across primary, secondary and tertiary education." [17]

Above referred theoretical review emphasis on the strategic planning of the sector in lieu of the concept of traditional planning of the plans it $s$ found that sustainable imitative to reduce the gender gap through comprehensive policies, plans and programs are missing in both plans 2014- to 2018, already implemented and the proposed plan for next 05 years also generally elaborate on literacy initiatives but the need of the hour is to address the challenge of the gender gap in the literacy as special initiatives in the new sector plan which is missing at large. This paper is written in that context to evaluate and analyses the achievements of the first plan Sindh education sector plan (SESP) 2014-18 in the detail and to discusses missing links in the proposed (SESP) plan 2019/20 -2023/24 for the next 05 years to be implemented in the region.

\section{OBJECTIVES OF THE STUDY}

The specific objectives of the study were to:

i. An evaluation of the Sindh school education sector plans

ii. Assessment of the plans in the context of gender policy on access.

iii. Examine sector plans bottlenecks and to provide feasible policy recommendations.

The study was guided by the following questions:

\section{RESEARCH QUESTIONS}

I. What is the real progress of the first education sector plan 2014-2018?

II. How has gender disparities addressed in both sector plans?

III. What are the bottlenecks in the plans and feasible recommendations? 


\section{SIGNIFICANCE OF THE STUDY}

The study reviewed the both sector plans in the dentils and sorted out major bottlenecks in the school sector plans and findings of the study can be used by the policymakers to set the realistic targets and improve the system required for quality education as driven demand in the region to reach the targets of quality education for all in the regions as globally planed in a great human interest.

\section{METHODOLOGY\& DATA}

The authors are serving in the education and literacy department for the last 02 decades so their observations as education experts, the outcome of specific and target groups, primary and secondary data of some individuals and organizations have been used to strengthen the hypothesis. The subject of development studies are mostly relies on qualitative methods of the research and it also emphasis on the secondary data of the relevant subject so that descriptive and explanatory the method is adapted in the paper. The qualitative /descriptive statistics the strategy has been adopted to identify the issues in Sindh School's education the sector with a ready reference to two plans in the public interest and in systemically order and also provides recommendations for further improvement for the greater cause of quality education for all in the region.

\section{DISCUSSIONS AND RESULT}

It has been analyzed on the basis of the evidence produced by the implementations of the first Sindh Education Sector Plan (SESP) 2014-18 that there are seven key priorities and strategies viz; "(i) Increasing Equitable Access to Early Childhood Education, Primary, Middle / Elementary and Secondary education; (ii) Improving the Curriculum and Learning Outcomes; (iii) Improving Teacher Quality; (iv) Strengthening Governance and Service Delivery; (v) Improving Resource Allocation; (vi) Adult Literacy and Non-formal Basic Education; and (vii) Cross-cutting areas (ICT, Education in Emergencies, Gender Equity, Social Cohesion, and Public-Private Partnerships for Education)", these further grouped into impact (Reduced poverty and vulnerability) and five outcomes/result areas to be addressed and monitored in the next 05 years plan, viz; first-one "Enhance sector governance and accountability", secondone "Improved Education Access \& Participation", third-one "Reduced disparity in education services", fourth-one "Improved Student Learning Outcomes and fifth-one Sustainable sector financing, detail are given in the Table-02 below. 
Table -02 First Sector Plan from (2014 to 2018)

Monitoring Framework and Key Performance Indicators

\begin{tabular}{|c|c|c|c|c|c|}
\hline \multirow{2}{*}{ Key Performance Indicators } & \multirow{2}{*}{$\begin{array}{l}\text { Baseline } \\
2011 / 12\end{array}$} & \multicolumn{4}{|c|}{ Targets } \\
\hline & & 2013 & 2014 & 2015 & 2018 \\
\hline \multicolumn{6}{|c|}{ I-IMPACT } \\
\hline \multicolumn{6}{|c|}{ Results Area: Reduced poverty and vulnerability } \\
\hline 1. \% children of out of school (Age $5-16$ ) & $40 \%$ & $38 \%$ & $35 \%$ & $30 \%$ & $23 \%$ \\
\hline $\begin{array}{l}\text { 2. Adult Literacy Rate (Aged } 10 \text { year and } \\
\text { older) }\end{array}$ & $59 \%$ & $62 \%$ & $65 \%$ & $67 \%$ & $77 \%$ \\
\hline \multicolumn{6}{|c|}{ II-OUTCOME } \\
\hline \multicolumn{6}{|c|}{ Results Area: 1. Enhance sector governance and accountability } \\
\hline 3. Teacher attendance rate & $85.30 \%$ & $87 \%$ & $89 \%$ & $91 \%$ & $96 \%$ \\
\hline 4. SEMIS ASC data accuracy & $46 \%$ & $50 \%$ & $55 \%$ & $65 \%$ & $85 \%$ \\
\hline $\begin{array}{l}5 . \% \text { of Education officials and teachers } \\
\text { receiving computerized ID no. \& smart } \\
\text { card }\end{array}$ & $0 \%$ & $30 \%$ & $60 \%$ & $80 \%$ & $100 \%$ \\
\hline $\begin{array}{l}\text { 6. \% of public schools (PS) randomly } \\
\text { monitored }\end{array}$ & - & $20 \%$ & $40 \%$ & $55 \%$ & $75 \%$ \\
\hline $\begin{array}{l}\text { 7. no. of public primary schools have head } \\
\text { teachers }\end{array}$ & 0 & 2,000 & 3,000 & 4,500 & 7,000 \\
\hline $\begin{array}{l}\text { 8. \% of SMC conduct election of the exec. } \\
\text { Committee }\end{array}$ & $20 \%$ (est.) & $30 \%$ & $45 \%$ & $65 \%$ & $90 \%$ \\
\hline $\begin{array}{l}\text { 9. \% of Non-functional government } \\
\text { schools }\end{array}$ & $10.50 \%$ & $9 \%$ & $7 \%$ & $5 \%$ & $2 \%$ \\
\hline $\begin{array}{l}\text { 10. No. of officials in the management } \\
\text { cadre receiving induction training }\end{array}$ & 0 & 1,000 & 2500 & 4000 & 7000 \\
\hline \multicolumn{6}{|c|}{ Results Area: 2. Improved Education Access \& Participation } \\
\hline $\begin{array}{l}\text { 11. Primary net enrolment rate (NER Age } \\
6-10)\end{array}$ & $59 \%$ & $60 \%$ & $63 \%$ & $66 \%$ & $77 \%$ \\
\hline $\begin{array}{l}\text { 12. Middle secondary net enrolment rate } \\
\text { (NER Age 11-13) }\end{array}$ & $32 \%$ & $33 \%$ & $35 \%$ & $38 \%$ & $50 \%$ \\
\hline $\begin{array}{l}\text { 13. Secondary net enrolment rate (NER } \\
\text { Age } 14-15 \text { ) }\end{array}$ & $19 \%$ & $20 \%$ & $22 \%$ & $24 \%$ & $30 \%$ \\
\hline $\begin{array}{l}\text { 14. Class } 1 \text { to } 2 \text { dropout rate in public } \\
\text { schools }\end{array}$ & $26.40 \%$ & $22 \%$ & $20 \%$ & $18 \%$ & $10 \%$ \\
\hline 15. Class 5 to 6 promotion rate in PS & $58.00 \%$ & $66 \%$ & $69 \%$ & $72 \%$ & $80 \%$ \\
\hline 16. Primary Completion Rate & $53 \%$ & $58 \%$ & $63 \%$ & $68 \%$ & $80 \%$ \\
\hline \multicolumn{6}{|c|}{ Results Area: 3. Reduced disparity in education services } \\
\hline $\begin{array}{l}\text { 17. Gender Parity Index (GPI) on Primary } \\
\text { GER }\end{array}$ & 0.77 & 0.78 & 0.8 & 0.82 & 0.87 \\
\hline 18. GPI on Middle Secondary GER & 0.81 & 0.82 & 0.83 & 0.84 & 0.88 \\
\hline $\begin{array}{l}\text { 19. Primary GER gap between best/worst } \\
\text { performing districts }\end{array}$ & $53 \%$ & $51 \%$ & $48 \%$ & $45 \%$ & $35 \%$ \\
\hline $\begin{array}{l}\text { 20. Middle Secondary GER gap between } \\
\text { best/worst performing districts }\end{array}$ & $51 \%$ & $49 \%$ & $47 \%$ & $45 \%$ & $32 \%$ \\
\hline $\begin{array}{l}\text { 21. Primary GER gap between } \\
\text { urban/rural }\end{array}$ & $31 \%$ & $29 \%$ & $27 \%$ & $26 \%$ & $20 \%$ \\
\hline 22. Middle GER gap between urban/rural & $37 \%$ & $35 \%$ & $33 \%$ & $30 \%$ & $25 \%$ \\
\hline \multicolumn{6}{|c|}{ Results Area: 4. Improved Student Learning Outcomes } \\
\hline & & & & & \\
\hline
\end{tabular}




\begin{tabular}{|c|c|c|c|c|c|}
\hline \multirow{2}{*}{ Key Performance Indicators } & \multirow{2}{*}{$\begin{array}{l}\text { Baseline } \\
2011 / 12 \\
\end{array}$} & \multicolumn{4}{|c|}{ Targets } \\
\hline & & 2013 & 2014 & 2015 & 2018 \\
\hline - $\%$ of class 3 pupils can read sentence & $33.80 \%$ & $35 \%$ & $37 \%$ & $40 \%$ & $45 \%$ \\
\hline $\begin{array}{l}-\% \text { of class } 3 \text { pupils can do math } \\
\text { subtraction }\end{array}$ & $22.20 \%$ & $25 \%$ & $27 \%$ & $30 \%$ & $35 \%$ \\
\hline \multicolumn{6}{|l|}{ 24. Class 4 students assessment results } \\
\hline - Language & $32 \%$ & $34 \%$ & $36 \%$ & $38 \%$ & $45 \%$ \\
\hline - Mathematics & $15 \%$ & $17 \%$ & $19 \%$ & $21 \%$ & $25 \%$ \\
\hline - Science & $19 \%$ & $21 \%$ & $23 \%$ & $25 \%$ & $32 \%$ \\
\hline 25. Class 8 students assessment results & \multirow{4}{*}{\multicolumn{5}{|c|}{ Baseline will be decided once result finalized }} \\
\hline - Language & & & & & \\
\hline - Mathematics & & & & & \\
\hline - Science & & & & & \\
\hline \multicolumn{6}{|c|}{ Results Area: 5. Sustainable sector financing } \\
\hline $\begin{array}{l}\text { 26. Education share of the overall } \\
\text { provincial expenditure outlay }\end{array}$ & $17 \%$ & $18 \%$ & $19 \%$ & $20 \%$ & $25 \%$ \\
\hline $\begin{array}{l}\text { 27. Education share of the total provincial } \\
\text { ADP Budget }\end{array}$ & $6.70 \%$ & $7.50 \%$ & $8.50 \%$ & $10.00 \%$ & $15 \%$ \\
\hline $\begin{array}{l}\text { 28. Salary share of the education current } \\
\text { budget }\end{array}$ & $80 \%$ & $79 \%$ & $77 \%$ & $75 \%$ & $65 \%$ \\
\hline $\begin{array}{l}\text { 29. Primary/Elementary and NFE share of } \\
\text { the education current budget }\end{array}$ & $\begin{array}{c}46.5 \% \\
(\text { FY } 2012 / 13)\end{array}$ & $46.50 \%$ & $46.50 \%$ & $46.50 \%$ & $45 \%$ \\
\hline
\end{tabular}

\section{Source: [6] Sindh Education Sector Plan 2014-2018 Page \# 316}

On the other hand, the second plan 2019-24 has eight priority areas to be addressed in the next 05 years plan with three groups one Equitable Access, two Quality and Learning, and three which is equally important Governance and Management to achieve the main objectives of the plan. The tables 03 of indicative activities in each priority program are included in the implementation plan. The eight Priority Programmes are: Out of school children and illiterate youth, Adequate and equitable provision of school infrastructure, Equitable enrolment and retention, Merit-based Teacher recruitment, qualifications and professional development, Quality inputs, and processes, Professional educational leadership and management cadre, Improved resource allocation, and utilization, Effective strategic planning and strengthening of the monitoring system with quality assessment of education in Sindh.

Table-03: 2nd Sindh Education Sector Plan 2019 to 2024-Targets

\begin{tabular}{|c|c|c|c|c|c|c|c|}
\hline S\# & Key performance Indicator & $\begin{array}{l}\text { Baseline } \\
2018\end{array}$ & $2019 / 20$ & $2020 / 21$ & $2021 / 22$ & $2022 / 23$ & $\begin{array}{c}2023 / 2 \\
4\end{array}$ \\
\hline & \multicolumn{7}{|l|}{ Equitable Access } \\
\hline & GER Primary & $81 \% *$ & $82 \%$ & $85 \%$ & $89 \%$ & $93 \%$ & $97 \%$ \\
\hline 1 & GER Middle & $39 \% *$ & $42 \%$ & $43 \%$ & $44 \%$ & $47 \%$ & $51 \%$ \\
\hline \multirow{2}{*}{2} & Completion rate Primary & $43 \% *$ & $43 \%$ & $46 \%$ & $51 \%$ & $56 \%$ & $62 \%$ \\
\hline & Completion rate Middle & $37 \% *$ & $41 \%$ & $42 \%$ & $42 \%$ & $43 \%$ & $45 \%$ \\
\hline 3 & $\begin{array}{l}\text { Secondary GER gap } \\
\text { between best/worst } \\
\text { performing districts }\end{array}$ & 49 points & 45 points & 41 points & 36 points & 31 points & $\begin{array}{c}25 \\
\text { points }\end{array}$ \\
\hline 4 & $\begin{array}{l}\text { Govt. post primary schools } \\
\text { as a percentage of govt. } \\
\text { primary schools }\end{array}$ & $11.15 \%$ * & $11.75 \%$ & $12.25 \%$ & $13.0 \%$ & $14 \%$ & $15 \%$ \\
\hline 5 & GPI Primary GER & $0.77^{*}$ & 0.77 & 0.77 & 0.79 & 0.81 & 0.83 \\
\hline
\end{tabular}




\begin{tabular}{|c|c|c|c|c|c|c|c|}
\hline & $\begin{array}{l}\text { GPI Middle GER } \\
\text { GPI Secondary GER }\end{array}$ & $\begin{array}{l}0.83^{*} \\
0.80^{*}\end{array}$ & $\begin{array}{l}0.83 \\
0.84\end{array}$ & $\begin{array}{l}0.83 \\
0.85\end{array}$ & $\begin{array}{l}0.83 \\
0.85 \\
\end{array}$ & $\begin{array}{l}0.83 \\
0.85\end{array}$ & $\begin{array}{l}0.85 \\
0.85\end{array}$ \\
\hline 6 & $\begin{array}{l}\text { No. of places available for } \\
\text { OOSC in NFE programmes }\end{array}$ & $\mathrm{N} / \mathrm{A}$ & 60,000 & 177,000 & 348,150 & 519,300 & 690,450 \\
\hline & \multicolumn{7}{|l|}{ Quality and Learning } \\
\hline 7 & $\begin{array}{l}\text { Percentage of teachers } \\
\text { participating in and } \\
\text { passing final evaluations of } \\
\text { cluster-based professional } \\
\text { development courses }\end{array}$ & 0 & $0 \%$ & $15 \%$ & $35 \%$ & $50 \%$ & $66 \%$ \\
\hline 8 & $\begin{array}{l}\text { Class } 5 \text { students } \\
\text { assessment results } \\
-\quad \text { Language } \\
-\quad \text { Mathematics } \\
\text { Science }\end{array}$ & $\begin{array}{c}32.8 \%+ \\
25.41 \%+ \\
21.48 \%+\end{array}$ & $\begin{array}{l}34 \% \\
27 \% \\
22 \%\end{array}$ & $\begin{array}{l}35 \% \\
27.5 \% \\
22.5 \%\end{array}$ & $\begin{array}{l}36.5 \% \\
28 \% \\
23.2 \%\end{array}$ & $\begin{array}{l}38 \% \\
29 \% \\
24 \%\end{array}$ & $\begin{array}{l}40 \% \\
30 \% \\
25 \%\end{array}$ \\
\hline 9 & $\begin{array}{l}\text { Class } 8 \text { students } \\
\text { assessment results } \\
-\quad \text { Language } \\
\text { - Mathematics } \\
\text { Science }\end{array}$ & $\begin{array}{l}39.85 \%+ \\
20.93 \%+ \\
25.89 \%^{+}\end{array}$ & $\begin{array}{c}41 \% \\
21.5 \% \\
26.2 \%\end{array}$ & $\begin{array}{l}42 \% \\
22.2 \% \\
27 \%\end{array}$ & $\begin{array}{l}43 \% \\
23 \% \\
28 \%\end{array}$ & $\begin{array}{l}44.5 \% \\
24 \% \\
29 \%\end{array}$ & $\begin{array}{l}46 \% \\
25 \% \\
30 \%\end{array}$ \\
\hline & \multicolumn{7}{|l|}{ Governance and Management } \\
\hline 10 & $\begin{array}{l}\text { Percentage of staff } \\
\text { assessed by new } \\
\text { Performance Management } \\
\text { System }\end{array}$ & $\mathrm{N} / \mathrm{A}$ & $6 \%$ & $16 \%$ & $32 \%$ & $48 \%$ & $66 \%$ \\
\hline 11 & $\begin{array}{l}\text { Percentage annual } \\
\text { utilization of non-salary } \\
\text { budgets }\end{array}$ & $66 \%$ & $70 \%$ & $72 \%$ & $77 \%$ & $81 \%$ & $85 \%$ \\
\hline 12 & $\begin{array}{l}\text { Number of districts } \\
\text { meeting KPI targets } \\
\text { annually }\end{array}$ & $\mathrm{N} / \mathrm{A}$ & 15 & 29 & 29 & 29 & 29 \\
\hline
\end{tabular}

[18].Government of Sindh, (2019). Sindh Education Sector Plan.2019-2024 (unpublished) * 2016/17+ SAT scores Sukkur IBA (2016/17)

It is observed that some of the main targets were not only ambitious targets but gender, as well as rural/urban segregations, were also missed, for instance, in 2011-12, Primary- Net Enrolment Ratio (NER) was 59, which was considered as a baseline of SESP 2014-15 and for the target of the year 2018 set 77 without further segregation (see detail in the Table-03 placed above: Key performance Indicator No. 11, under the heading '2. Improved Education Access \& Participation') and even reports since 2008-09 were showing a declining trend, therefore, it was a need of more efforts as well as resources for even halted the NER ratios and for the significant improvement there were infrastructure and more resources required to adjust the retained enrollment. Later on, report shows that Primary - NER is stagnant at $61 \%$ as shown in figure 01 . This figure is based on various (PSLM) reports.

\section{Figure 01}

Net Enrolment Rate (NER) -

Primary level (age 6-10) (excluding katchi class)

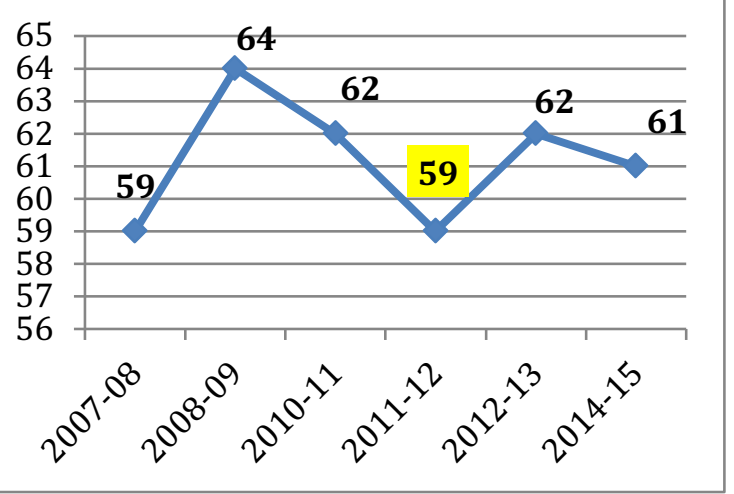


Similarly, the ambitious target set for primary/post- primary ratio, baseline ratio quoted 91\% / 9\% and target of primary/post- primary ratio set for 2018 is 70\% / 30\% without addressing the gender and Urban/Rural aspects.[20] Apparently, the primary/post- primary ratio in census 2016-17 showing little improved 90\% / 10\% but this is mainly due to School Consolidation reform wherein as per legal covenant merged schools name and SEMIS code eliminated from the master school database. Therefore, census data showing that overall 3,656 number of schools reduced (from 46,039 in 2014-15 to 42,383 in 2016-17), most of them were primary. [21]

It is important to highlight that in some targets of 2018 there were no / low/negative progress observed in the last 05 years as shown in remarks of serial number 01 of part one where ten points are negative in progress which alarming for policymakers of the region. However, targets given in the serial no $02,03,04$ and 05 are observed ambitious and no/low progress.

Table-04: Sindh Education Sector Plan (SESP) 2014-18 Targets of 2018 Vs Base line of SESP 2019-24

\begin{tabular}{|c|c|c|c|}
\hline & & SESP & $19-24$ \\
\hline S\# & KPI & $\begin{array}{c}\text { Baseline } \\
2018\end{array}$ & $\begin{array}{c}\text { Target } \\
2023 / 24\end{array}$ \\
\hline 1 & $\begin{array}{l}\text { Completion rate } \\
\text { Primary }\end{array}$ & $43 \% *$ & $62 \%$ \\
\hline 2 & $\begin{array}{l}\text { Secondary GER gap } \\
\text { between best/worst } \\
\text { performing districts }\end{array}$ & 49 points & 25 points \\
\hline 3 & $\begin{array}{l}\text { Govt. post primary } \\
\text { schools as a } \\
\text { percentage of govt. } \\
\text { primary schools }\end{array}$ & $11.15 \%$ & $15 \%$ \\
\hline & GPI Primary GER & 0.77 & 0.83 \\
\hline 4 & GPI Middle GER & $0.83^{*}$ & 0.85 \\
\hline & $\begin{array}{l}\text { Class } 5 \text { students } \\
\text { assessment results }\end{array}$ & & \\
\hline 5 & - Language & $32.8 \%+$ & $40 \%$ \\
\hline & - Science & $21.48 \%+$ & $25 \%$ \\
\hline
\end{tabular}

\begin{tabular}{|c|c|c|c|}
\hline \multicolumn{2}{|c|}{ SESP 2014-18 } & \multirow[b]{2}{*}{$\begin{array}{l}\text { Progress } \\
\text { Vs } \\
\text { Target of } \\
2014-18\end{array}$} & \multirow[b]{2}{*}{$\begin{array}{l}\text { In the light of SESP } \\
\text { 2018, Unfinished } \\
\text { targets. } \\
\text { [Baseline 2018 - } \\
\text { Target 2018] }\end{array}$} \\
\hline $\begin{array}{l}\text { Baseline } \\
2011 / 12\end{array}$ & $\begin{array}{c}\text { Target } \\
2018 / 19\end{array}$ & & \\
\hline $53 \%$ & $80 \%$ & -37 & $\begin{array}{l}\text { Not Achieved, even } 10 \\
\text { points decreased from } \\
\text { the baseline of SESP } \\
2014-18\end{array}$ \\
\hline 51 & 32 & 17 & $\begin{array}{l}\text { Not Achieved, } 17 \\
\text { points yet to be } \\
\text { reduced }\end{array}$ \\
\hline $9 \%$ & $30 \%$ & -19 & $\begin{array}{l}\text { Not Achieved, } 19 \\
\text { points yet to be } \\
\text { achieved }\end{array}$ \\
\hline 0.77 & 0.87 & -10 & $\begin{array}{l}\text { Not Achieved, No } \\
\text { Progress observed }\end{array}$ \\
\hline 0.81 & 0.88 & -5 & $\begin{array}{l}\text { Not Achieved, from } \\
2011 \text { to } 2018 \text { only } 2 \\
\text { points progress this } \\
\text { may be due to girls } \\
\text { stipend and other } \\
\text { reforms }\end{array}$ \\
\hline & & & $\begin{array}{l}\text { in SESP 2014-18 (Page } \\
317) \text { Class } 4 \text { is } \\
\text { mentioned }\end{array}$ \\
\hline $32 \%$ & $45 \%$ & -12 & $\begin{array}{l}\text { Not Achieved, From } \\
\text { SAT } 2012 \text { to SAT } \\
\text { 2016-17 less than } 1 \\
\text { points improvement }\end{array}$ \\
\hline $19 \%$ & $32 \%$ & -11 & $\begin{array}{l}\text { Not Achieved, From } \\
\text { SAT } 2012 \text { to SAT } \\
\text { 2016-17 less than } 3 \\
\text { points improved }\end{array}$ \\
\hline
\end{tabular}

Though Sindh Education Sector Plan (SESP) 2014-15 is a provincial level holistic frame-work however, later on, it was realized the dearth of the district level frame-work for that district 
education Group (DEG) was formed to participate in consultative sessions for the development of District Education Plans. However, in the Sector plan 2019-20, district aspect is not covered.

\section{Student Learning Outcomes in the first sector Plan 2014-18}

This is a fact that quality education planned in the sector plans are measured by the testing of the students in various fields by the reputed third part but it's no dynamic change reflected in the table-05. Student learning outcomes, tested through various assessments across grades and across subjects, have shown some improvement since the beginning of the plan 20142018, but are still quite low, as can be seen in table-03 in the details. The change in language quality increased from 29.50 to 33.46 only the measured change is only $04 \%$ in the 05 years planning of the sector. The progress in an important subject of mathematics' is almost the same increased from 17.09 to 21.72 . The subject of science progress increase is only $02 \%$ which alarming as tested in the class of 5 which is the last class of primary schoolings. The result of middle schooling students is not quite satisfactory.

The overall Language performance is increased from 37.01 to 46.16 but math's and science's overall performance increase is $2 \%$ and $3 \%$ percent in real figures. The urban, rural and separate male and female results are also not attractive progress as planned within the 05 years plan framework. The real figure of the increase in urban-rural and gender is from 01 to $2 \%$ only as shown in columns 04 to 07 in detail. At aggregate level, it can be concluded that the progress of the first sector plan is not up to the mark because of a lack of proper implementations strategy, financial crunch and ineffective governance for proper fund utilization in the fields. The traditional planning strategy in theoretical order was the major obstacle and cause of the failure of the Sindh Education Sector Plan (SESP) 01 implemented from 2014 to 2018.

Table-05: Student Achievements Test scores in Classes 5 and 8 by subject, gender, and geographic area2014 and 2018.

\begin{tabular}{|c|c|c|c|c|c|c|}
\hline \multicolumn{2}{|c|}{ 2013-14 } & \multicolumn{4}{|c|}{ 2017-18 } & \\
\hline \multicolumn{7}{|c|}{ Class 5} \\
\hline & Total & Total & Urban & Rural & Male & Female \\
\hline LANGUAGE & 29.50 & 33.46 & 32.52 & 33.71 & 32.82 & 34.67 \\
\hline МАТН & 17.09 & 21.72 & 21.97 & 21.72 & 21.96 & 21.28 \\
\hline SCIENCE & 17.74 & 19.14 & 20.16 & 18.64 & 18.93 & 19.55 \\
\hline \multicolumn{7}{|c|}{ Class 8} \\
\hline LANGUAGE & 37.01 & 46.16 & 45.93 & 46.24 & 44.51 & 48.69 \\
\hline МАТН & 13.73 & 15.85 & 15.97 & 15.73 & 15.55 & 16.32 \\
\hline SCIENCE & 17.07 & 21.92 & 22.49 & 21.38 & 20.82 & 23.59 \\
\hline
\end{tabular}

[22] Source : SAT score Sukkur IBA University (2016/17) unpublished.

\section{Second Sindh School Education Sector Plan from (2019 to 2024)}

The given above table-04 elaborates details of the Sindh education sector plan to be implemented from 2019 to 2024 in serial number 01 and 02 gross enrollment is shown in the base year of 2018 is $81 \%$ and $39 \%$ and target proposed is 97 and $51 \%$ within 05 years which beyond the reality if we compare the progress of the past plan 2014-2018.The completion rate of primary from 43 to $62 \%$ is also unjustified because of slow implementations process in the field and lack of resource and they're thinly utilizations as observed in the past. There is a huge crisis of the governance in Sindh Pakistan so the gap between worst performing district cannot reduce up to $25 \%$ easily in the next five years. Targets mentioned at serial no 04 to 12 are mostly justified but again need to tackles the gender issue in the plan as special initiatives in the proposed plans/policies and programs for the welfare of the girls in the regions. It is very 
important that the proposed sector plan is prepared at the province level but actual implementation will be covered at the district level in the field so the need to address the problems at the grassroots level should be focused on the district level for effective implementations as strategic and evidence-based planning. One side should be linked with national and another important side it should be at district level.

6.3 Need for sustainable plan: In Sindh, 10,115 (24\%) out of 42,383 School having 2,882,623 (68\%) enrolment, however, a large number of Schools 32,268 (76\%) having 1,346,505 (32\%) enrolment (pictorial way is depicted in figure 02, Taking the same concept further, there is a need for prioritizing the high enrolment 4,524 Schools across Sindh with the overall objective of attending to the infrastructure and academic environment of these schools holistically. It was supposed that not only foregoing reform reflect in the sector plan 2019-24 but also a plan to work on remaining high priority and high enrollment Schools of the second proposed plan for the next o5 years. Moreover, the model's dichotomy indicates the crucial need for viability assessment of the schools to know the causes where no / low / less potential schools reported.
Figure 02 24\% Schools have 68\% enrolment and $76 \%$ Schools have only $32 \%$ enrolment

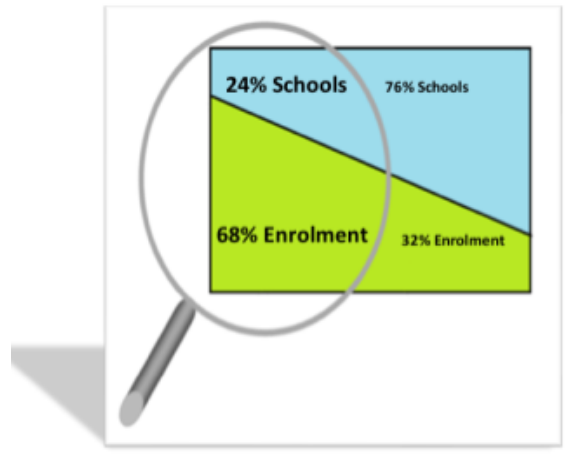

[21] Sindh-EMIS 2016-17

Another significant issue is that the Sindh province is divided into natural zones like hilly zone, desert zone, delta zone, coastal zone plain areas which are agricultural-based and urban centers i.e Karachi, Hyderabad and Sukkur centers. The urban centre's and plain/prosper agricultural zones people are more literate in comparison of desert, mountains and costal/delta zones. The uniformity based traditional sector plan could not bring change in the field and the same fate will be faced the future which will be no failure and no success of the sector plan as faced in the past.

\section{CONCLUSIONS AND POLICY RECOMMENDATIONS}

This is concluded that strategic planning should be base on the data /information of the subject to take the right steps to resolve the real issue /challenge in the fields So that net and clean data requires for comprehensives and strategic planning. It is the personal observation of the author that the challenge of astonishing data in enrolment besides with biased and unbiased statistics errors in the Sindh is major obstacles in implementations of the plans. So if we decide for long terms planning, the data collection system should be improved for sustainable evidence-based planning in the education sector. It is suggested that the year 2019 ended and the targets of sustainable development goals (SDGs) are till 2030, so ideally thinking the duration of the plan should be at least 10 years (2020-2030). so that following three main objectives should be achieved one alignment with national and sustainable development goals (SDGs-2030), targets, and two special focus of each the institution who contributed, for instance, educations policymakers may focus on preparation work, planning approvals in year one (2020) then may focus on early childhood care and education (ECCE) in year second in all aspects such as development of ecce classrooms, trained teachers, curriculum, etc and in the last two years may be a special focus on the examination board reforms. It is the need of the hour to draft ten years plan for this key sector of the human development in the province with alignments of national-level planning in the country. Every year there should be a Joint 
Education Sector Review (JESR), and after every review an updated version of the Sector plan may be published which should indicate the progress against all indicators, as well as new recommendations, also incorporated with revised targets (if any). There is a need for setting evidence-based and achievable targets. Not only year-wise provincial targets of all indicators / key progress indicators (KPIs), but plan should have segregation of the district level targets so that district performance may also track and rewarded. Moreover, It is also proposed that in for every review of targets, either setting new reforms or unfinished key progress indicators (KPIs), all may be assesses with the new the approach of 'lenses triple' " $\mathrm{A}$ " analysis (ㅅuthority, Acceptance, and Ability) for the opportunity of "space for change", This changing space is subject on contextual factors normally found to influence policy and reform success, determining what and how much can be done in any reform initiative or activity at any time, this is very useful approach wherein through Venn diagram with large, middle and low buffers one can know the area of challenge(s) and this analysis is also useful to identify where to start, in this connection "Large Change Space" is a good area where the activity needs to be started first. However, if any "small change space" or "No Change Space" that can be either resolve first, then reform may continue OR explore other alternatives possibilities (detail given figure 03.

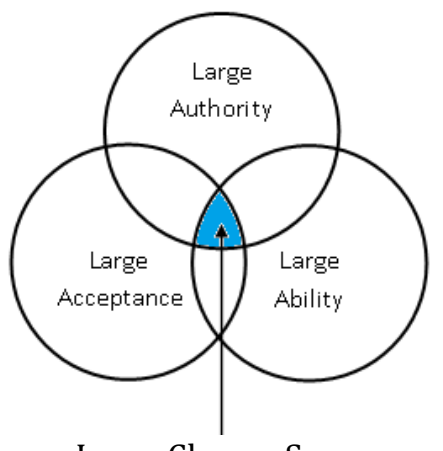

Large Change Space

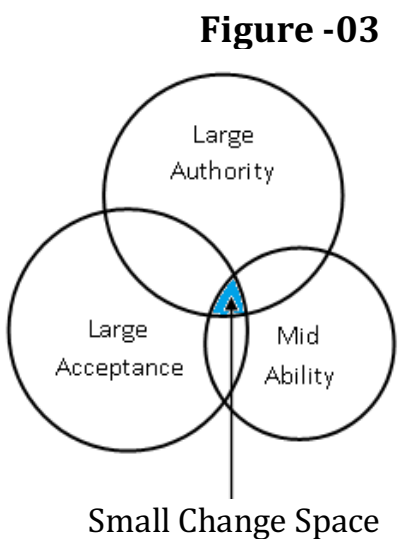

Small Change Space

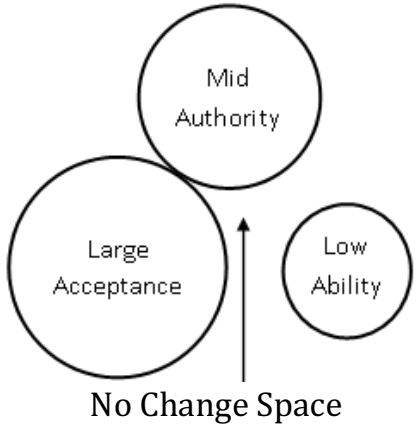

No Change Space

It is also concluded there are missing links observed in an Empirical Analysis of Sindh Education Sector Plans of Enhancing Education Access to all in Sindh Pakistan so that the plan may be revised in a comprehensive way to incorporate special initiatives on gender development in greater national and human interest. It is suggested that randomly verify the performance evaluation of all the plans every month. And suggest means for improvement in the plans with help of the counties is very necessary for quality education for all in the regions. The sector plan should be prepared as per the available challenges' of the zones then we should able to achieve the given detentions of quality education for all up to 2030. This is also concluded that a comprehensives strategy for monitoring and evaluation of the plans is not properly part of the plan and without it, results could not be measured in the long term planning. The result produced in the meeting of plans is generally assumed because of technical errs in the monitoring system due to old collections and observations method. So, for comprehensive strategic and evidence-based planning progress from the field should be collected and analyzed with modern tools and techniques. Result base management system may be introduced in the department to monitor the real progress of the plan and suggest a guideline for speedy implementations. It is also concluded and suggested that the special plan to fill the gap of gender access to girls and zone wise parts of the plan may be incorporated on an urgent basis to face the reality in the different zones. The development partners including international donor's organizations and parents, teachers associations should be consulted in 
the whole process of sector planning to make the plan as strategic planning and result based initiatives' with large authority, ability and acceptability for large change space in the region.

\section{References:}

U. N. (2019), World Population Prospects 2019. New York: United Nations, Department of Economic and Social Affairs, Population Division.

Pakistan Bureau of Statistics, "2017 Population Census of Pakistan” Government of Pakistan Islamabad UNDP (2018), Human Development Indices and Indicators: 2018 Statistical Update, Pakistan.

Pakistan Government of (2014-15), Economic Survey of Pakistan. Islamabad, Ministry of Finance \& Economic Affairs Division. pp 156.

Government of Sindh, 2019. Situational Analysis of the Education Sector in Sindh.(unpublished).

Sindh Education Sector Plan 2014-2018, School Education \& Literacy Department Government of Sindh Karachi Pakistan.pp316

Caroline Pearce and Kjersti J. Mowé,(2014) Planning matters in education 'page 38, Global Campaign for Education 2014. 25 Sturdee Avenue, Rosebank, Johannesburg 2132, South Africa www.campaignforeducation.org

Lawrence Summers, "Investing in All the People: Educating Women in Developing Countries," World Bank, EDI Seminar Paper, No. 45. Washington, D.C. (1994) p.1.

Klasen, Stephan. "Low Schooling for Girls, Slower Growth for All? Cross-Country Evidence on the Effect of Gender Inequality in Education on Economic Development." The World Bank Economic Review 16, no. 3 (2002): 345-373.

Husain, F., Qasim, M.A. and Sheikh, K.H., 2003. An analysis of public expenditure on education in Pakistan. The Pakistan development review, 42(4), pp.771-780.

Parveen, S., 2008. Female education and national development: As viewed by women activists and advocates. Three Bulletin of Education and Research, 30, pp.33-41.

Dauda, R.O.S., 2012. Does female education promote economic performance? Evidence from Nigeria. International Journal of Economics and Finance, 5(1), p.201

Syeda Anam Hassan\& Nazish Rafaz(2016) The Role of Female Education in Economic Growth of Pakistan: A Time Series Analysis from 1990-2016. International Journal of Innovation and Economic Development 3.5 (2017): 83-93.

Tagar Hamzo Khan (2019.) The low Female Literacy Trends: A Critical Challenge of Human Development in Pakistan (Major Obstacles and Way Forward) ABR volume 6 N06 pp.

Chang, G.C.; Radi, M. 2001. Educational planning through computer simulation. Education policies and strategies, 3. Paris: UNESCO.http://inesm.education.unesco.org/fi les/124209e.pdf

IIEP-UNESCO. 2010a. Strategic planning: Concept and rationale. Education sector Planning, Working paper 1. Paris: IIEP-UNESCO. http://unesdoc.unesco.org/images/0018/001897/189757e.pdf

Global Gender Report (2020) of World Economic Forum 2020 Geneva, Switzerland.

Government of Sindh, (2019). Sindh Education Sector Plan 2019-2024 (unpublished).

Pakistan Bureau of Statistics, S. D. (2008 -2016). Pakistan social and living standards measurement survey various repots Islamabad: Government of Pakistan, Statistics Division.

Sindh-EMIS, S. E. (2015). Sindh Education Profile 2014-15. Karachi: Reform Support Unit (RSU), School Education \& Literacy Department (E\&LD) Government of Sindh (GoS).

Sindh-EMIS, S. E. (2017). Sindh Education Profile 2016-17. Karachi: Reform Support Unit (RSU), School Education \& Literacy Department (E\&LD) Government of Sindh (GoS).

Student Achèvement Test Score Report Sukkur IBA University (2016/17)- unpublished. 